\title{
A KISTÉRSÉGI TERVEZÉS NÉHÁNY SAJÁTOSSÁGA ${ }^{1}$
}

(Specific Features of Planning in Micro-regions)

\author{
G. FEKETE ÉVA
}

Az 1996-ban elfogadott Területfejlesztési Törvény a területfejlesztési tervezés rendszerébe beépítette a kistérségi szintü koncepciók készítését és ennek felelőseként az önkormányzatok kistérségi fejlesztési társulásait nevezte meg. Ugyanakkor az elmúlt időszak felülröl kezdeményezett térségfejlesztési programjai is prioritásként, helyenként a további támogatásokhoz való hozzájutás feltételeként szabták meg a kistérségi fejlesztési stratégiák, programok meglétét. Már eddig is számtalan kistérségi fejlesztési stratégia készült és a jövőben még több megfogalmazása, sőt folyamatos kistérségi tervezés kialakulása várható. Így nem érdektelen az ebben a témakörben összegyült tapasztalatok, illetve azok néhány szeletének összegzése. Jelen mondanivalómat három kérdésre kívánom korlátozni:

- Miben különbözik a kistérségi tervezés a megyei és a regionális szintü tervezéstöl?

- Hogyan alakítható a kistérségi tervezés menete?

- Milyen eltérések adódnak a fejlettebb és a fejletlenebb kistérségekben folyó tervezés során?

A kistérségi, illetve a megyei és regionális tervezés közötti első és leglényegesebb különbség a megrendelö személyéböl adódik. A kistérségi tervezést elindító kistérségi fejlesztő szervezetek (a valóságban nem csupán önkormányzati társulások!) helye még labilis a magyar területfejlesztési szervezeti rendszerben. Bár a Területfejlesztési Törvény megnevezi, sőt tervezési feladatokkal látja el őket, ehhez semmilyen eszközt nem rendel. A tervezéssel foglalkozó apparátus kialakulásához nem ad forrásokat, így a kistérségi tervezés vagy valamely települési önkormányzat tevékenységébe beágyazottan, vagy a civil szféra - igencsak szük lehetöségei között marad. A lényeg az, hogy a megrendelö saját anyagi és szellemi forrásokkal nem rendelkezik a munka elvégzéséhez.

Ennek megfelelöen a motiváció is változik. A kistérségek egy része pályázati forrásokból azért szerzett támogatást, mert valóban fontosnak tartotta tevékenységének tervszerü mederbe terelését, más részük azért készíttetett fejlesztési stratégiát, mert éppen ehhez lehetett támogatást szerezni. A két motiváció gyakran kétféle végeredményre is vezetett. Ügyes szakmai koncepció esetében meg volt az esély, hogy a hosszú távú munkában valóban használható terv készül, és elindul a folyamatos tervezési folyamat, míg a második esetben gyakorta a fióknak készulitek el a tervdokumentumok.

A második különbség a tervezés alapegységében rejlik. A kistérségi tervezés csakis alulról építkezhet, alapegységei a települések. Települési fejlesztési elképzelések nélkül kistérségi stratégia nem készithető, de a kistérségi stratégia nem egyenlő a települési fejlesztési ötletek mechanikus összegével. A tervezés során meg 
kell találni a települések összessége által alkotott térség sajátos fejlesztési forrásait és érdekeit, ki kell emelni a térségi prioritásokat. Ugyanakkor a kistérségi tervnek súlya, hatása csak akkor van, ha az konszenzuson alapul.

A konszenzus elérésére és a helyi eröforrások minél alaposabb feltárására irányuló törekvések miatt a kistérségi tervezésben a helyi szereplök bevonásának meghatározó szerep jut. Helyi szereplökön azonban nem lehet csupán az önkormányzatokat, a polgármestereket érteni, a helyi vállalkozók, intézmények, tekintélyes emberek, civil szervezetek bevonása nem csupán a konszenzus kialakításához, de a stratégia megvalósításában való motiváltság erősítéséhez, a megvalósítás garanciáinak kiépüléséhez is elengedhetetlen. A kistérségi tervezés során a helyiek intenzív részvétele azonban azt eredményezi, hogy a tervezés folyamata és maga a terv a napi gondokhoz és a laikusokhoz közelebb, a szakmától távolabb kerül.

Éppen a fenti sajátosságból adódóan, a kistérségi tervezésnél a szakértô szerepe is különbözik a megyei és regionális tervezésben való részvételtöl. Itt nem csupán az elkészült dokumentum helyiekkel való egyeztetését kell elvégeznie, hanem a helyi munkacsoportokat végig kell vezetnie a tervezés folyamatán. Nem csupán az ágazati szakértelmére, hanem speciális, a közösségfejlesztéshez, csoportépítéshez, konfliktuskezeléshez kapcsolódó képességeire is szükség van. Munkája nem ér véget a dokumentum megfogalmazásával, a megrendelö többnyire elvárja a megvalósításban való részvételt is, az ezzel járó szakértői dijjak kifizetésére pedig általában nincs, vagy nem kiszámítható rendszerességgel van lehetősége. Talán nem véletlen, hogy a tervezési folyamat azokban a kistérségekben vált a legsikeresebbé, ahol a külsö szakértöi bázist a térség iránt valamilyen okból elkötelezett, önkéntes munkában is dolgozni hajlandó szakértökböl sikerült felépiteni.

A nemzetközi gyakorlatban szokásos térségfejlesztési tervezés menetét, abban a helyi csoport és a szakértöi munka súlypontjait kívánom áttekinteni az alábbiakban, és helyenként kiegészíteni néhány, a hazai tapasztalatokból leszürhető megállapitással.

\section{A földrajzi terület körvonalazása}

Egy hipotézis vagy munkaterület felállítása, amit rendszerint a megrendelö végez.

\section{Emberek bevonása}

A tervezés helyi munkacsoportjának kialakitása helyismeret nélkül nem megy. A szükséges ismeret vagy a külső szakértök terepmunkája, vagy eleve a megrendelö javaslatai alapján érhetö el.

\section{A földrajzi terület pontos lehatárolása}

Bármennyire is megkötöttséget és esetleg létező kötődések látszólagos szétvágását jelenti bármilyen lehatárolás, a kistérségi stratégiakészítés során nem kerülhető meg, hiszen a későbbiekben a helyi fejlesztési források pontos feltáráshoz adatainkat valamilyen területre összegeznünk kell. A földrajzi terület lehatárolásakor tekintettel kell lennünk arra a sajátosságra, hogy a gazdasági fejlesztések optimális területi mérete rendszerint nagyobb, míg az alulról építkező tervezéshez és a megvalósításhoz szükséges közösségi összefogás optimális és lehetséges területi 
mérete rendszerint kisebb térséget jelöl ki. Az ellentmondás - véleményem szerint a kisebb, 10-15 településből álló mikrokörzetekből felépülō térség meghatározásával, azaz egy kettős területi lépték alkalmazásával oldható fel. A fóldrajzi terület pontos lehatárolását a késöbbi konfliktusok elkerülése végett célszerü a helyi munkacsoporttal együtt, csoportmunkában elvégezni.

\section{Rövid helyzetelemzés}

A térség néhány mondatos meghatározása kiindulási alapot jelent a részletes helyzetfeltáráshoz, felhívja a figyelmet a legproblémásabb, ill. a fejlesztés bázisát jelentő területekre. Ez csoportmunkában végezhető el.

\section{Az alapértékek tisztázása}

A helyiek bevonásával történő tervezés talán legnehezebb része a fejlesztési stratégia általuk elfogadható és megvalósítható irányait alapvetöen meghatározó értékrendszer feltárása. Az értékeket ugyanis a legritkább esetben fogalmazták meg eddig maguknak, ill. általában nem konzisztens értékrenddel rendelkeznek. A csoportmunkát elöre elkészített tesztlapok alkalmazásával tehetjük hatékonnyá.

\section{Fejlesztési hipotézis felállitása}

Még mindig csoportmunkában, a helyi fejlesztési elképzeléseket gyüjtjük csokorba és felvázolunk egy elôzetes jövőképet. A javaslatok között lehetnek megalapozatlan vágyálmok is, melyeket a későbbiek során ki kell szürnünk.

\section{Részletes helyzetértékelés}

A klasszikus szakértői munka csak ebben a fázisban kezdődik. A rővid helyzetelemzés és a fejlesztési hipotézis szempontjait elötérbe helyezố helyzetfeltárás során - a korábbi gyakorlattól kissé idegen módon - különősen ügyelnünk kell a piaci szemlélet érvényesítésére, a belső kompetenciák feltárására és a partnerek meghatározására. Különősen a kompetenciák feltárása idō- és munkaigényes, költségei a helyi munkacsoport önkéntes munkájának bevonásával csőkkenthetők.

\section{Forgatókönyvek felvázolása}

A szakértők a helyzetfeltárás és szakmai ismereteik alapján megrajzolják a térség fejlődésének lehetséges forgatókőnyveit.

9. SWOT - analizis

A helyzetfeltárás eredményeinek ismeretében, csoportmunkában történhet a térség erösségeinek, gyengeségeinek a kívülröl adódó lehetöségeknek és veszélyeknek a feltárása. A csoportmunkát a kollektiv bölcsesség elve mellett a tervvel való azonosulás követelménye is megkívánja.

\section{Jövôkép megfogalmazása}

A fejlesztési hipotézist tőkéletesitve, az elvégzett munka eredményeivel ütkőzetve fogalmazza meg és fogadja el a csoport a fejlesztési stratégia alapját képező jövőképet. 


\section{Fejlesztési célok és azok prioritási sorrendjének meghatározása}

$\mathrm{Ez}$ is csoportmunkában történik. Vigyázni kell arra, hogy ne keveredjenek a célok a feladatokkal.

\section{Alapstratégia választása}

A legtöbb kistérségi stratégiából ma még nem derül ki, hogy mi is stratégiájuk lényege. A szakértő feladata a tisztázott értékrend és célok alapján a területi tudományok elméleti ismereteinek birtokában a lehetséges alternativák (exportorientáció, innováció-orientáció, jóléti, fenntartható fejlödés, stb.) felvázolása.

\section{Fejlesztési feladatok, a fö programok meghatározása}

A feladatok meghatározása is csoportmunkában történik, de ezen a ponton különösen ügyelni kell arra, hogy az ismeretek hiánya miatt nehogy nagyon beszüküljön a stratégia. Abban, hogy ne minden kistérségben a gyógynövénygyủjtést és a falusi turizmust akarják fejleszteni, részint a külsö szakértöknek van felelőssége, részint képzéssel, tanulmányúttal, más példák megismertetésével, a megyei és regionális stratégiákban szereplő irányokból adódó lehetöségek, az innovációs központokhoz való kapcsolódás lehetőségeinek elemzésével kerülhető el. A fejlesztési feladatok prioritásainak megfelelően fogalmazandók meg a fö programok.

\section{A fejlesztés feltételrendszerének kialakitása}

A stratégiaalkotás befejezéséhez minimálisan szükséges a fejlesztés szervezeti- és intézményrendszere, a finanszírozás lehetösége és a kapcsolódó PR tevékenységek meghatározása, ami alapvetöen szakértöi munka. A szervezeti rendszer kialakitásánál ajánlatos figyelembe venni a térségfejlesztés kettős földrajzi léptékét.

\section{A fejlesztési programok kimunkálása}

Az eddigi hazai gyakorlatban általában eddig már nem jut el a kistérségi tervezés, vagy ez a fázis elszakad az előzőektől. A programok kidolgozását mindenkor célszerü szakértökre bizni. Ez a szakértelem azonban már különbözik az elöző fázisban igényelttől, többnyire ágazatokhoz kötődik.

\section{Akcióterv készitése}

Az elkészült szakmai program alapján, de a megvalósítás szereplöi közötti munkamegosztás rendjét velük együtt tisztázó munkafázisban ismét megjelenik a csoportmunka.

\section{Projekttervek, megvalósithatósági tanulmányok készitése}

Tisztán ágazati szakértelmet igénylő tevékenység. A mai gyakorlatban egyet jelent a pályázatok elkészitésével.

A folyamatot áttekintve azt hiszem, nyilvánvaló, hogy a tervezés kistérségi koordinációja, a helyiek munkájának szervezése, majd a megvalósítás során is a partnerek együttmüködésének szervezése embert, méghozzá föállású szakértőt vagy 
szakértôket igénylö feladat. Az alkalmazás feltételeinek biztositásában és az alkalmazottak kiképzését biztosító felsőfokú képzési formák támogatásában az államnak alapvető felelössége és feladatai vannak.

A fejlettebb és fejletlenebb térségtípusok közötti különbségek összefoglalásával nem csupán a tervezés számára nyerhetünk újabb, a hatékonyságot növelö adalékokat, de az esélyek területi kiegyenlítődésének néhány aspektusára is felhívhatjuk a figyelmet.

A fejlettebb térségekben az alulról építkező tervezés, illetve fejlesztés elindítása nehézkesebb, mert erösebbek a belsö konfliktusok, nagyobb a belsö rivalizálás. A fejletlenebb térségekben, ahol már egyértelmüvé vált, hogy egyedül nem képesek a települések saját fejlődésüket elindítani, a térségi összefogásra, igy a kistérségi tervezésre is nagyobb a motiváció, könnyebben jutnak el az együttmüködés szándékáig.

Már a tervezés folyamatában is megnyilvánul, hogy a fejlettebb térségekben a helyi munkacsoport kreativitása erösebb, jobban biztositottak a humán feltételek. Ugyanakkor több anyagi eröforrással is rendelkeznek. Ezen feltételek hiánya az elmaradott térségekben csak visszafogottabb tervek készítését teszi lehetövé. Különösen kiviláglik a különbség a fejlesztési programok kidolgozásánál, majd megvalósításánál.

A fejlettebb térségben nagyobb a valószínüsége, hogy a tervben meghatározott programok megvalósitása rövidebb időn belül elkezdödik, hiszen a jelenlegi támogatási rendszerben a meglévő nagyobb belső eröforrásokhoz könnyebb a külső eröforrásokat mozgósítani. Ugyanakkor a fejletlenebb térségekben a szükösebb belső erőforrások miatt a külső szakértő segítségére inkább igényt tartanak a megvalósítás során is, mint a fejlettebb, saját szakértői gárdával rendelkező térségben, ám ezért a segítségért kevésbé tudnak fizetni.

A fentiek alapján kitünik, hogy az alulról építkező, önerös fejlesztési stratégiák megfogalmazódásának és megvalósulásának esélyei lényegesen jobbak a fejlettebb térségekben. Az esélyek közelítése az elmaradott térségekben folyó, a helyiekkel való együttmüködésen alapuló külső és a belső együttmüködés szervezésére, a fejlesztési folyamat összefogására hivatott belső szakértöi munka külső finanszirozásával és a programok helyi sajátosságokat is figyelembe vevő, eltérő mértékủ támogatásával lehetséges.

\section{Jegyzetek}

${ }^{1}$ Az elöadás A területi tervezés új kihívása: a területfejlesztési koncepció c. konferencián hangzott el. (Győr, 1997. április 3-4.) 